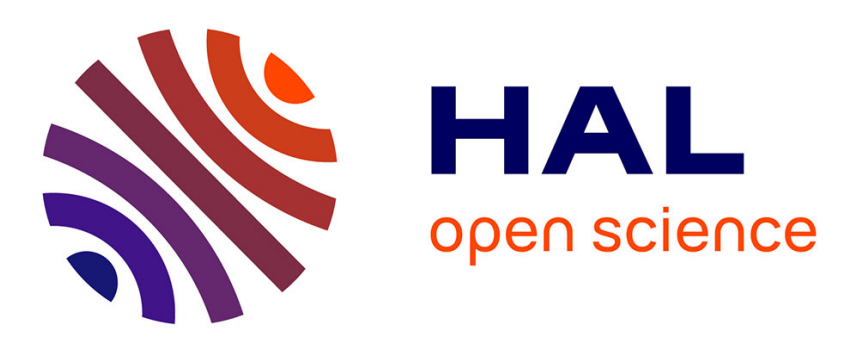

\title{
The association between periodontitis and non-alcoholic fatty liver disease: a systematic review
}

\author{
Mohammad Sultan Al-Alakhali, Sadeq Ali Al-Maweri, Hashem Motahir \\ Al-Shamiri, Esam Halboub, Khaled Al-Haddad
}

\section{- To cite this version:}

Mohammad Sultan Al-Alakhali, Sadeq Ali Al-Maweri, Hashem Motahir Al-Shamiri, Esam Halboub, Khaled Al-Haddad. The association between periodontitis and non-alcoholic fatty liver disease: a systematic review. Clinical Oral Investigations, 2018, 22 (9), pp.2965-2974. 10.1007/s00784-0182726-1 . hal-03168637

\section{HAL Id: hal-03168637 \\ https://hal.science/hal-03168637}

Submitted on 18 Mar 2021

HAL is a multi-disciplinary open access archive for the deposit and dissemination of scientific research documents, whether they are published or not. The documents may come from teaching and research institutions in France or abroad, or from public or private research centers.
L'archive ouverte pluridisciplinaire HAL, est destinée au dépôt et à la diffusion de documents scientifiques de niveau recherche, publiés ou non, émanant des établissements d'enseignement et de recherche français ou étrangers, des laboratoires publics ou privés. 
Title suggestions:

The association between periodontitis and non-alcoholic fatty liver disease: a systematic review

Authors: Mohammad Sultan Al-Akhali ${ }^{1}$, Sadeq Ali Al-Maweri ${ }^{2}$, Hashem M Al-Shamiri ${ }^{3}$, Esam Halboub $^{4}$, Khaled Alhadad ${ }^{5}$

${ }^{1}$ Department of Periodontology, Faculty of Dentistry, Jazan University, Jazan, Saudi Arabia

${ }^{2}$ Department of Oral Medicine and Diagnostic Sciences, AlFarabi Colleges for Dentistry and Nursing, Riyadh, Saudi Arabia. Email: $\underline{\text { Sadali05@hotmail.com }}$

${ }^{3}$ Department of Oral and Maxillofacial Surgery, AlFarabi Colleges for Dentistry and Nursing, Riyadh, Saudi Arabia. hashem_alshamiri@yahoo.com

${ }^{4}$ Department of Maxillofacial Surgery and Diagnostic sciences, College of Dentistry, Jazan University, Jazan, Saudi Arabia.

5Department of Orthodontic and Pediatric Dentistry, College of Dentistry, Sana'a University, Sana'a, Yemen

\section{Corresponding:}

Dr Mohammad Sultan Al-Akhali

Department of Periodontology, Faculty of Dentistry,

Jazan University, Jazan, Saudi Arabia 


\begin{abstract}
Objectives: Animal and human studies have shown associations between periodontitis and non-alcoholic fatty liver disease (NAFLD). The purpose of the present systematic review was to assess the association between periodontitis and NAFLD

Methods: This systematic review aimed to answer the focused question "Is there any association between periodontitis and NAFLD?" PubMed/ Medline, Scopus, Embase, and Web of Science databases were thoroughly searched to identify all relevant studies using the following keywords: periodontal disease, periodontitis, periodontal health, gingival health, periodontal pathogens, NAFLD, and hepatic steatosis. Due to marked heterogeneity and inconsistency in the included studies, no statistical analyses were conducted.
\end{abstract}

Results: A total of 12 studies comprising 53,384 patients were included in the present systematic review. The sample size in the included studies ranged from 52 to 24,470 patients. All studies except one found significant associations between clinical and/or microbial periodontal parameters and NAFLD.

Conclusions: The available evidence suggests that periodontitis may be a risk factor for development and progression of NAFLD. However, due to limited number of prospective cohort studies included in this review, and the substantial heterogeneity among the included studies, further well- designed prospective cohort studies are highly warranted.

Keywords: Periodontitis, NAFLD, association, systematic review 


\section{Introduction:}

Periodontitis is a chronic disease of the tooth supporting structures characterized by immunological breakdown of bone and soft tissues in response to the bacterial dental plaque (Meyle and Chapple, 2015). It is one of the most common chronic diseases with an estimated rank of being the $6^{\text {th }}$ most prevalent long-term disease worldwide (GBD 2015 Disease and Injury Incidence and Prevalence Collaborators, 2016). When untreated or unsuccessfully treated, it ultimately leads to progressive loss of attachment, tooth mobility and, in severe cases, tooth loss with associated cost burden (Kassebaum et al., 2014a, Kassebaum et al., 2014b, Listl et al., 2015). Worthy to mention that its health impact crosses the boundaries of oral cavity as it has been reported to be associated with many systemic diseases (Linden et al., 2013) including, but not limited to, cardiovascular diseases (Beukers et al., 2017), chronic obstructive pulmonary disease (Chung et al., 2016), pneumonia (Gomes-Filho et al., 2014), chronic kidney disease (Deschamps-Lenhardt et al., 2018), rheumatoid arthritis (Potempa et al., 2017), cognitive impairment and dementia (Gil-Montoya et al., 2015), metabolic syndrome (Kumar et al., 2016) and cancer (Corbella et al., 2018). Otherwise, periodontal therapy results in glycemic control in diabetic patients (Hasuike et al., 2017, Li et al., 2015). Such an argument supports the concept of "periodontal medicine" which emphasizes on the importance of bidirectional oral-systemic link (Gulati et al., 2013, Kumar, 2017). Recently, many animal and human studies have linked periodontitis with non-alcoholic fatty liver disease (NAFLD) (Akinkugbe et al., 2017b, Alazawi et al., 2017, Komazaki et al., 2017, Nakahara et al., 2018, Yoneda et al., 2012).

NAFLD is a condition in which $\geq 5-10 \%$ of hepatocytes reveal macroscopic steatosis upon light microscope examination in the absence of other etiologic risk factors of liver disease. It represents a spectrum of liver disease ranging from simple steatosis (non-alcoholic fatty liver) to 
non-alcoholic steatohepatitis (Neuschwander-Tetri and Caldwell, 2003). The former shows a non-progressive clinical course, while the latter is a more serious form of NAFLD. Being associated with features of the metabolic syndrome and has a similar global prevalence of $25 \%$ (Araujo et al., 2018), NAFLD predisposes individuals to type 2 diabetes and cardiovascular diseases (Anstee et al., 2013). Additionally, untreated NAFLD predispose to liver cirrhosis and hepatocellular carcinoma and the subsequent need for liver transplantation (Ponziani et al., 2018). Many risk factors for the development of NAFLD have been reported including obesity, diabetes, insulin resistance, oxidative stress and inflammation [1-6, from Yoneda]. Recent studies, as noted above, have also reported a link between periodontitis and NAFLD.

Periodontitis and NAFLD are assumed to share (associated with) many common risk factors: namely obesity, diabetes, and insulin resistance. Owing to its subclinical and persistent nature, periodontitis is considered a mild chronic disease with systemic effects. In addition to the elevated blood levels of many inflammatory markers in periodontitis patients (Loos et al., 2000), which have been accused to predispose to many systemic manifestations including NAFLD , periopathogenes injection to mice have been reported to be a risk factor for NAFLD (Nakahara et al., 2018). A number of epidemiological and clinical studies have recently evaluated the association between periodontitis and NAFLD (Included studies). However, the published studies on potential association between periodontitis and NAFLD are scarce, of different designs and with conflicting results. Therefore, the present systematic review was conducted to answer the following question: Is periodontitis a risk factor for non-alcoholic fatty liver disease? 


\section{Materials and methods:}

\section{Focused question:}

This systematic review was conducted following the Preferred Reporting Items for Systematic Review and Meta-Analysis (PRISMA) guidelines (Moher et al., 2015). The PECO research question that guided this review was: Is chronic periodontitis a risk factor NAFLD?

\section{Eligibility criteria:}

The eligibility criteria were as follows: clinical observational studies, cross-sectional studies, case-control, cohort studies, case series or case reports that assessed the relationship between periodontitis and NAFLD in humans. Exclusion criteria were in-vitro studies, pure animal studies, review papers, monographs, conference papers, letters to editors, unpublished data, and studies published in a language other than English.

\section{Literature search:}

A literature search was conducted through PubMed/Medline, Scopus, Embase, and Web of Science (ISI) databases to identify all relevant articles published in English from date of inception up to May 30, 2018, using the following keywords in different combination: periodontal disease; periodontitis; periodontal health; gingival health; periodontal pathogens; non-alcoholic fatty liver diseases (NAFLD); and hepatic steatosis.

Titles and abstracts of retrieved articles were screened by two authors (SA and MA) and irrelevant studies were excluded. Full texts of articles obtained from the previous step were read and evaluated independently by the two authors for inclusion. Moreover, the reference lists of included articles were manually searched for additional studies.

Our initial aim was to conduct meta-analysis but due to marked heterogeneity and inconsistency of data among the included studies, no statistical analysis was performed.

\section{Assessment of quality:}

Critical appraisal of the included studies was performed by two independent authors. Criteria for assessing the quality of studies were adapted from the Strengthening the Reporting of Observational 
studies in Epidemiology Statement (STROBE). Seven criteria were considered the most important ones in context of this review and were included in the checklist (Vandenbroucke et al., 2014).

The STROBE checklist comprised the following: whether the study design is clearly stated, study participants are fully described, sample size is justified, variables are clearly defined, potential confounders are addressed, outcomes are accurately measured and appropriate statistical analysis tests were used. Each criterion was given a response of either "Yes" or "NO". Each study could have a maximum score of 7 . After the scores were summed, the methodological quality was graded as low (0-3), acceptable (4-5), and high (6-7).

\section{Data extraction:}

The following data were extracted by two independent authors using a standard data collection form: authors and year of study; country; study design; age and gender of patients; number of patients; clinical and microbial periodontal parameters, NAFLD parameters, and main outcomes. 


\section{Results:}

\section{Search Results}

The PRISMA flowchart for identification of relevant studies is presented in figure1. The first electronic and manual literature search retrieved a total of 137 studies collected from various databases $($ Embase $=23$, Web of Science $=28$, PubMed $=65$, and Scopus $=21)$. After removal the duplicate studies, 57 studies were screened through their titles and abstracts, of which 34 studies were found irrelevant and thus excluded. Only 23 publications were eligible for full text evaluation. Of these, 12 studies (Ahmad et al., 2015, Furusho et al., 2013, Furuta et al., 2010, Hyvarinen et al., 2009, Kuraji et al., 2016, Lins et al., 2011, Nagao et al., 2014, Saito et al., 2006, Takamura et al., 2016, Tomofuji et al., 2009, Vasconcelos et al., 2017, Widita et al., 2018) have been excluded for some reasons( Table1). One

publications (Alazawi et al) reported on two independent studies, both of which were eligible for inclusions. Eventually, 11 publications (Akinkugbe et al., 2017a, Akinkugbe et al., 2018, Akinkugbe et al., 2017b, Alazawi et al., 2017, Komazaki et al., 2017, Morita et al., 2014, Nakahara et al., 2018, Omura et al., 2016, Yoneda et al., 2012) comprising 12 studies were eligible for inclusion in this systematic review and processed for data extraction.

\section{General characteristics:}

Out of the 137 retrieved studies, 12 studies obtained from nine publications involving 53,384 patients were included in the present systematic review (Akinkugbe et al., 2017a, Akinkugbe et al., 2018, Akinkugbe et al., 2017b, Alazawi et al., 2017, Komazaki et al., 2017, Morita et al., 2014, Nakahara et al., 2018, Omura et al., 2016, Yoneda et al., 2012). With respect to study design, nine studies were crosssectional (Akinkugbe et al., 2017a, Alazawi et al., 2017, Komazaki et al., 2017, Morita et al., 2014, Nakahara et al., 2018, Yoneda et al., 2012), one prospective cohort (Akinkugbe et al., 2017b), one retrospective observational (Nakahara et al., 2018) and one was a case report (Omura et al., 2016). Six studies were conducted in Japan (Komazaki et al., 2017, Morita et al., 2014, Nakahara et al., 2018, Omura et al., 2016, Yoneda et al., 2012), two in the USA (Akinkugbe et al., 2018, Alazawi et al., 2017), two in Germany (Akinkugbe et al., 2017a, Akinkugbe et al., 2017b), one in China ( $\mathrm{mmmmmm}$ ) and one in England (Alazawi et al., 2017). The sample size in these studies ranged from 52 to 24,470 patients. The mean age of the participants was reported in 9 studies (refrence), which ranged from 39.2 to 51.5 years. All studies except one (Alazawi et al., 2017) reported gender of the participants (Table 1). 
NAFLD parameters: Regarding diagnosis and assessment progression NAFL condition, biochemical data were used in all included studies (all studies ), computed tomography and/or Ultrasound was used in 10 studies (Akinkugbe et al., 2017a, Akinkugbe et al., 2017b, Alazawi et al., 2017, Komazaki et al., 2017, Nakahara et al., 2018, Omura et al., 2016, Yoneda et al., 2012), and biopsy findings were used in only 4 studies (Alazawi et al., 2017, Nakahara et al., 2018, Omura et al., 2016, Yoneda et al., 2012).

Periodontal parameters: Seven studies (Akinkugbe et al., 2017a, Akinkugbe et al., 2018, Akinkugbe et al., 2017b, Alazawi et al., 2017) assessed clinical periodontal parameters that included one or more of the following: clinical attachment level (CAL), periodontal pockets (PD), bleeding upon probing, or community periodontal index (CPI). One study assessed both clinical and microbial parameters (Alazawi et al., 2017). The remaining four studies (Komazaki et al., 2017, Nakahara et al., 2018, Omura et al., 2016, Yoneda et al., 2012) evaluated microbial parameters: bacterial loads including prophyromonas gingivalis (P.g)using PCR (Yoneda et al., 2012); IgG antibody titers to three periopathic bacteria including Aggregatibacter actinomycetemcomitans (Aa), Fusobacterium nucleatum (Fn), Porphyromonas gingivalis (Komazaki et al., 2017); IgG antibody titers to P.g (Nakahara et al., 2018); and isolation of P.g (Omura et al., 2016) (Table 2).

\section{Main outcomes:}

All included studies except one (Akinkugbe et al., 2018) revealed a significant association between clinical and/or microbial periodontal parameters and NAFLD progression.

Akinkugbe et al 2017 (Akinkugbe et al., 2017b) in their large population-based prospective cohort study investigating the epidemiological association of periodontitis and the incidence of NAFLD among 2,623participants from Pomerania, Germany found a significant association between periodontitis and NAFLD. The findings showed a significantly higher incidence of NAFLD in subjects with moderate and severe CAL periodontitis compared to periodontally healthy participants even after adjusting for potential confounders. The authors observed a dose-response relationship in the incidence of NAFLD in relation to severity of CAL periodontitis. Similar results were seen in PD periodontitis but with no dose-response relationship. The investigators concluded that periodontitis might be an independent risk factor for NAFLD. In another cross-sectional study by Akinkugbe et al 2017 (Akinkugbe et al., 2017a) evaluating the role of Genetic Markers of Inflammation (serum C-reactive protein (CRP) in modifying the Relationship between periodontitis and NAFLD, the findings revealed a significant positive association 
between periodontitis and the prevalence odds of NAFLD, and such relationship was modified by serum CRP levels.

In one cross-sectional study (reference) investigating the relationship between periodontitis and NAFLD among Japanase adults found that periodontitis was significantly associated with NAFLD. The authors concluded that $\mathrm{PD}>4 \mathrm{~mm}$ could be a risk factor to NAFLD.

Another cross-sectional study (Reference) in China $(n=24,470)$ found that number of missing teeth was significantly associated with presence of NAFLD.

Furthermore, ALazawi (Alazawi et al., 2017) and colleagues conducted two separate studies to ascertain the association between periodontitis and NAFLD: one population-based survey (Alazawi et al., 2017) that based on data from NHANES III participants $(n=8,172)$; and another clinical hospital-based study involving biopsy-proven NAFLD patients (Alazawi et al., 2017). In the epidemiological based study, authors found a significant correlation between periodontitis (CAL and PD) and NAFLD even after adjustment for potential confounders. Moreover, the authors found some significant correlation between hepatic steatosis and serum antibodies to certain oral pathogens especially S. noxia and S. oralis. Similar association was replicated in the hospital-based study, with stronger association was noted in patients with advanced liver fibrosis. Additionally, Morita et al 2014 (Morita et al., 2014) observed that ALT and GGT levels were higher in patients with periodontal pockets depth (PPD $\geq 4 \mathrm{~mm}$ ) compared to healthy controls. (Alazawi et al., 2017).

However, in a large-scale cross-sectional study conducted by Akinkugbe et al 2018 (Akinkugbe et al., 2018), among Hispanic community $(n=11,914)$, the authors did not find any significant association between periodontitis and NAFLD after controlling for potential confounders.

In the four pure microbial studies, investigators found a significant association between periopathogens and NAFLD. Yoneda et al (Yoneda et al., 2012) investigated the frequency of P.g. in 150 biopsy-proven NAFLD patients and 60 healthy controls using PCR, and found a significant higher frequency of P.g in NAFLD patients than healthy controls (46.7\% vs. $21.7 \%$, odds ratio: 3.16 ). The authors also noted that the non-surgical periodontal treatment carried out on 10 NAFLD patients for 3 months has improved the liver function parameters. The authors concluded that P.g is a risk factor for progression of NAFLD (Yoneda et al., 2012). Similarly, Nakahara et al (Nakahara et al., 2018) reported a significant correlation between the progression of NAFLD and serum antibodies titre against P.g ().Komazaki et al 
(Komazaki et al., 2017) also reported a significant correlation between the progression of NAFLD and serum antibodies titre against Aa and Fn (Komazaki et al., 2017).

Omura et al (Omura et al., 2016) reported a 54 year-old Japanese female with nonalcoholic liver cihrosis who died of sepsis caused by a periodontal pathogen . Computed tomography revealed that the patient had liver cirrhosis with massive ascites, and oral examination revealed severe periodontitis with tendency for bleeding. The patient had no history of drinking habits. The oral flora Parvimonus micra, a periodontal pathogen, was identified in her blood. The autopsy findings revealed nonalcoholic fibrosis of the liver, and on immunohistochemical staining, P.g was detected in the hepatocytes.

\section{Discussion:}

Findings from animal and human studies have suggested a relationship between periodontal diseases and NAFLD. However, no attempt has been made to systematically review the available evidence on the association between these two chronic health conditions. Hence, the present systematic review was envisioned to address a focused research question, "Is periodontal disease a risk factor for NAFLD?". The literature search identified 12 eligible studies that were reviewed and qualitatively analyzed. All of these studies reported on clinical and/or microbiological periodontal parameters in relation to NAFLD. Interestingly, all studies except one (Akinkugbe et al 2018) found a statistically significant association between periodontal parameters and NAFLD, and further portrayed periodontitis as an independent risk factor for NAFLD progression. Nevertheless, it is pertinent to mention that due to relatively low number of included studies especially cohort studies and the substantial heterogeneity among these studies, the findings of the present review should be interpreted with caution.

Periodontal diseases have already been linked to numerous systemic disorders including diabetes mellitus, hypertension, coronary heart diseases, stroke, and metabolic syndrome, demonstrating the impact of periodontal inflammation at systemic level. The exact mechanism by which periodontitis is linked to NAFLD is still unclear. One possible biological explanation is the low-grade inflammatory nature of periodontitis that elicits systemic inflammation. Low-grade (Chronic) inflammation is pivotal to pathogenesis of obesity-related insulin resistance, a precursor to NAFLD, which in turn contributes to the initiation and progression of NAFLD (Hotamisligil, 2006). The elevated lipopolysachraides and proinflammatory cytokines initiated by P.g, a gram negative periopathogen, have been reported to induce and worsen insulin resistance (Santos Tunes et al 2010) (Panormia study), a condition involved in the pathogenesis of NAFLD (Alam et al., 2016). 
Another possible biological explanation is the alteration in gut microbial composition resulting from the swallowed periodontal pathogens especially P. gingivalis (Arimatsu et al 2014) . The P.g.- induced endotoxins and lipopolysaccharides stimulate hepatocytes and trigger production of cytokines and reactive oxygen species, eventually leading to liver injury and initiation of NAFLD (demmer et al 2016). P.gingivalis, a gram negative bacteria, is the main causative agent for periodontitis. Interestingly, all included microbial studies found a significant association between periodontal pathogens especially $\mathrm{P}$. gingivalis and NAFLD progression (Microbial). Yoneda et al found a significant higher frequency of P.g in NAFLD patients than healthy controls (46.7\% vs. $21.7 \%$, odds ratio: 3.16$)$. Moreover, the same authors noted that the infection of type II P. gingivalis on NAFLD mouse model accelerated the NAFLD progression. Another clinical study (Nakhara et al) also revealed a significant correlation between the progression of NAFLD and serum antibodies titre against P.gingivalis . Also Omura et al., reported isolation of p.g from hepatocytes of a 54 -year-old NAFLD female patient who died of acute sepsis. Our findings support previous reports that linked P.gingivalis to several systemic diseases such as .....

Periodontal treatments aim to eliminate the inflammation and reduce the bacterial load. Among the included studies, only one study (Yoneda et al 2012) investigated the effect of periodontal treatment on NAFLD. The authors observed a significant improvement in liver function parameters (ALT and AST) after successful non-surgical periodontal treatment. These findings suggest that clinical periodontal improvement could have supportive effects in ameliorating severity of NAFLD, and also strengthens the correlation between periodontal diseases and NAFLD.

Biopsy is the gold standard for diagnosis NAFLD. However, ultrasonography is more appropriate for population-based studies (Qaio et al 2018). In our review, although most of the included studies used imaging means and/or biopsy to characterize NAFLD, two studies (Akinkugbe 2018; Morita et al) relied only on biochemical data such as ALT and AST to identify NAFLD. ALT and AST, serum aminotransminase, are non-specific markers of hepatocytes injury and are not always elevated in NAFLD. Thus, the incidence of outcome (NAFLD) might have not been precisely estimated in the latter two studies, and so the results might have been biased.

Although the available evidence from this review supports the association between periodontitis and NAFLDs, there are several limitations worth considering. One main limitation is the relative small number of studies included, and the great heterogeneity among these studies; therefore no meta-analysis was attempted to quantify the magnitude of the association. Another important limitation is related to the 
study designs of the included studies, with most of the studies were cross-sectional and only one prospective cohort study, and hence it is difficult to infer causality. Another shortcoming is related to generalization of the results as half of the reported studies were conducted in one country (Japan), and therefore, it is hard to extrapolate the findings to other populations. Further, the marked variability in methods of characterizing both the exposure (periodontal parameters) and the outcome (diagnosis of NAFLD) is an obvious limitation of the present review. However, despite these limitations, this review has several strengths. First, this is the first systematic review to summarize the current evidence on the associations between periodontitis and NAFLD. Second, the study is strengthened by the relative large population size $(53,384)$ and by including both clinical and microbial studies that evaluated the relationship between periodontitis and NAFLD.

In conclusion, the available evidence suggests that periodontitis may be associated with NAFLD. However, due to limited number of prospective cohorts studies and heterogeneity among these studies, further large- scale prospective cohort studies with long follow up periods targeting different ethnic populations are highly recommended.

\section{Compliance with ethical standards:}

Conflict of interests: The authors declare that they have no conflict of interest.

Ethical approval: This is a review article and so no ethical approval is required.

Funding: We did not receive any external funding 
Table1: List of excluded studies

\begin{tabular}{|l|c|}
\hline \multicolumn{1}{|c|}{ Study } & $\begin{array}{c}\text { Reason for } \\
\text { exclusion }\end{array}$ \\
\hline Hyvärinen et al (2009) & animal study \\
\hline Widita et al (2017) & Non-NAFLD \\
\hline Ahmad et al (2015) & Non-NAFLD \\
\hline Furuta et al (2010) & Non-NAFLD \\
\hline Saito et al (2006) & Non-NAFLD \\
\hline Nagao et al (2014) & Non-NAFLD \\
\hline Takamura et al (2016) & animal study \\
\hline Tomofuji et al (2009) & animal study \\
\hline Vasconcelos et al(2017) & animal study \\
\hline Furusho et al (2013) & animal study \\
\hline Lins et al (2011) & Non-NAFLD \\
\hline Kuraji et al (2016) & animal study \\
\hline
\end{tabular}


Table 2: General characteristics of the included studies

\begin{tabular}{|c|c|c|c|c|c|c|c|}
\hline $\begin{array}{l}\text { Author and } \\
\text { country }\end{array}$ & $\begin{array}{l}\text { Study } \\
\text { design }\end{array}$ & $\begin{array}{c}\text { No } \\
\text { Participants }\end{array}$ & Gender & $\begin{array}{l}\text { Mean } \\
\text { age/ } \\
\text { range }\end{array}$ & $\begin{array}{l}\text { NAFLD diagn } \\
\text { Parameters }\end{array}$ & $\begin{array}{l}\text { Periodontal } \\
\text { parameters }\end{array}$ & Main outcome \\
\hline $\begin{array}{l}\text { Akinkugbe } 2018 \\
\text { USA }\end{array}$ & $\begin{array}{l}\text { Cross- } \\
\text { sectional }\end{array}$ & $\begin{array}{l}11,914 \\
\text { NAFLD: } 18.1 \%\end{array}$ & $\begin{array}{l}\text { M: } 45.1 \% \\
\text { F: } 54.9 \%\end{array}$ & 40.4 & $\begin{array}{l}\text {-ALT } \\
\text {-AST } \\
\text {-FLI }\end{array}$ & -CAL \& PD & $\begin{array}{l}\text { Marginal to null association } \\
\text { between periodontitis and } \\
\text { NAFLD. }\end{array}$ \\
\hline $\begin{array}{l}\text { Akinkugbe et al } \\
2017 \\
\text { Germany }\end{array}$ & $\begin{array}{l}\text { Prospective } \\
\text { Cohort }\end{array}$ & 2,623 & $\begin{array}{l}\text { M: } 1,074 \\
\text { F: } 1549\end{array}$ & 46 & $\begin{array}{l}\text {-Ultasound } \\
\text {-ALT level }\end{array}$ & -CAL, PD & $\begin{array}{l}\text { periodontitis is an } \\
\text { independent risk factor for } \\
\text { NAFLD }\end{array}$ \\
\hline $\begin{array}{l}\text { Akinkugbe et al } \\
2017 \text { Germany }\end{array}$ & $\begin{array}{l}\text { Cross- } \\
\text { sectional }\end{array}$ & $\begin{array}{l}2481 \\
\text { NAFLD: } 654\end{array}$ & $\begin{array}{l}\text { M: } 1,116 \\
\text { F: } 1365\end{array}$ & 47 & -Ultrasound & $\begin{array}{l}\text {-CAL, PD } \\
\text { - CRP }\end{array}$ & $\begin{array}{l}\text { Periodontitis was associated } \\
\text { with higher prevalence odds } \\
\text { of NAFLD and this relation } \\
\text { was modified by serum CRP } \\
\text { levels. }\end{array}$ \\
\hline $\begin{array}{l}\text { Alazawi et al } \\
2017 \text { USA }\end{array}$ & $\begin{array}{l}\text { population- } \\
\text { based survey }\end{array}$ & 8,172 & $\begin{array}{l}\text { M: } 3796 \\
\text { F: } 4376\end{array}$ & $20-74$ & $\begin{array}{l}\text {-Ultrasound } \\
\text {-Biochemical }\end{array}$ & $\begin{array}{l}\text { - PPD } \\
\text {-CAL } \\
\text {-bleeding } \\
\text {-Microbial }\end{array}$ & $\begin{array}{l}\text { NAFLD is associated with } \\
\text { periodontitis especially with } \\
\text { advanced liver fibrosis. Also, } \\
\text { steatosis was associated with } \\
\text { serum antibodies of } \\
\text { periodontal bacteria. }\end{array}$ \\
\hline $\begin{array}{l}\text { Alazawi et al } \\
2017 \\
\text { England }\end{array}$ & $\begin{array}{l}\text { cross- } \\
\text { sectional }\end{array}$ & 69 NAFLD & NA & $>18$ ys & $\begin{array}{l}\text {-Biopsy-proved } \\
\text {-Ultrasound } \\
\text {-Histological }\end{array}$ & PD & $\begin{array}{l}\text { periodontitis correlated } \\
\text { significantly with stage of } \\
\text { liver disease, }\end{array}$ \\
\hline $\begin{array}{l}\text { Iwasaki } 2018 \\
\text { Japan }\end{array}$ & $\begin{array}{l}\text { Cross- } \\
\text { sectional }\end{array}$ & 1226 & $\begin{array}{l}\text { M: } 772 \\
\text { F: } 454\end{array}$ & 50 & $\begin{array}{l}\text { Ultrasound } \\
\text { Biochemical }\end{array}$ & PD & $\begin{array}{l}\text { Significant association } \\
\text { between periodontitis and } \\
\text { NAFLD }\end{array}$ \\
\hline $\begin{array}{l}\text { Qiao et al } 2018 \\
\text { China }\end{array}$ & $\begin{array}{l}\text { Cross- } \\
\text { sectional }\end{array}$ & 24,470 & $\begin{array}{l}\text { M: } 49.9 \% \\
\text { F: } 50.1 \%\end{array}$ & 39.2 & Ultrasound & missing teeth & $\begin{array}{l}\text { missing teeth were associated } \\
\text { with higher presence of } \\
\text { NAFLD in males. }\end{array}$ \\
\hline $\begin{array}{l}\text { Morita et al2014 } \\
\text { Japan }\end{array}$ & $\begin{array}{l}\text { Cross- } \\
\text { sectional }\end{array}$ & 1510 & $\begin{array}{l}\text { M: } 1218 \\
\text { F: } 292\end{array}$ & 50.4 & $\begin{array}{l}\text { ALT } \\
\text { GGT }\end{array}$ & CPI & $\begin{array}{l}\text { Periodontal disease is } \\
\text { associated with liver function }\end{array}$ \\
\hline $\begin{array}{l}\text { Yoneda et al } \\
2012\end{array}$ & $\begin{array}{l}\text { Comparative } \\
\text { cross- } \\
\text { sectional }\end{array}$ & $\begin{array}{l}150 \text { NAFLD } \\
60 \text { Controls }\end{array}$ & $\begin{array}{l}\text { M: } 64 \\
\text { F: } 86\end{array}$ & 54.6 & $\begin{array}{l}\text {-Histological } \\
\text {-Ultrasound } \\
\text {-ALT, ASP, } \\
\text { GGT }\end{array}$ & $\begin{array}{l}\text {-PD } \\
\text {-Microbial } \\
\text {-PCR assay }\end{array}$ & $\begin{array}{l}\text { Significantly higher } \\
\text { Frequency of P. gingivalis in } \\
\text { NAFLD/ NASH patients than } \\
\text { controls. }\end{array}$ \\
\hline $\begin{array}{l}\text { Komazaki et al } \\
2018 \\
\text { Japan }\end{array}$ & $\begin{array}{l}\text { Cross- } \\
\text { sectional }\end{array}$ & 52 NAFLD & $\begin{array}{l}\text { M:27 } \\
\text { F: } 25\end{array}$ & 55 & $\begin{array}{l}\mathrm{CT} \\
\text {-Biochemical } \\
\text { tests }\end{array}$ & -Microbial & $\begin{array}{l}\text { Aa and Fn antibodies titres } \\
\text { were significantly correlated } \\
\text { with NAFLD. }\end{array}$ \\
\hline $\begin{array}{l}\text { Nakahara et al } \\
2018 \\
\text { Japan }\end{array}$ & $\begin{array}{l}\text { Retrospective } \\
\text { observational }\end{array}$ & 200 NAFLD & $\begin{array}{l}\text { M: } 94 \\
\text { F: } 106\end{array}$ & 51.5 & $\begin{array}{l}\text {-Biochemical } \\
\text {-Histological } \\
\text {-CT }\end{array}$ & -Microbial & $\begin{array}{l}\text { A significant correlation } \\
\text { between fibrosis progression } \\
\& \text { anti- P.g antibody titers }\end{array}$ \\
\hline $\begin{array}{l}\text { Omura et al } 2015 \\
\text { Japan }\end{array}$ & Case report & 1 & - & 54 & $\begin{array}{l}\text { Blood analysis } \\
\text { CT } \\
\text { autopsy }\end{array}$ & P. gingivalis isolation & $\begin{array}{l}\text { P. gingivalis was detected in } \\
\text { the hepatocytes of NASH } \\
\text { patient }\end{array}$ \\
\hline
\end{tabular}


Table 3: STROBE -based quality analysis of the included studies.

\begin{tabular}{|c|c|c|c|c|c|c|c|c|c|}
\hline$\#$ & Reference & $\begin{array}{l}\text { Study } \\
\text { design }\end{array}$ & Participants & $\begin{array}{c}\text { Sample } \\
\text { size }\end{array}$ & $\begin{array}{c}\text { Variable } \\
\text { description }\end{array}$ & $\begin{array}{c}\text { Potential } \\
\text { confounders }\end{array}$ & $\begin{array}{c}\text { Outcome } \\
\text { measurements }\end{array}$ & $\begin{array}{c}\text { Statistical } \\
\text { analysis }\end{array}$ & $\begin{array}{l}\text { Total } \\
\text { score }\end{array}$ \\
\hline 1 & Akinkugbe 2018 & 1 & 1 & 1 & 1 & 1 & 1 & 1 & 7 \\
\hline 2 & Akinkugbe et al 2017 & 1 & 1 & 1 & 1 & 1 & 1 & 1 & 7 \\
\hline 3 & Akinkugbe et al 2017 & 1 & 1 & 1 & 1 & 1 & 1 & 1 & 7 \\
\hline 4 & Alazawi et al 2017 & 1 & 1 & 1 & 1 & 0 & 1 & 1 & 6 \\
\hline 5 & Alazawi et al 2017 & 1 & 1 & 1 & 1 & 0 & 1 & 1 & 6 \\
\hline 6 & Iwasaki et al 2018 & 1 & 1 & 0 & 1 & 1 & 1 & 1 & 6 \\
\hline 7 & Qiao et al 2018 & 1 & 1 & 1 & 1 & 1 & 1 & 1 & 7 \\
\hline 8 & Morita et al 2014 & 1 & 1 & 0 & 1 & 1 & 1 & 1 & 6 \\
\hline 9 & Yoneda et al 2012 & 1 & 1 & 0 & 1 & 0 & 1 & 1 & 5 \\
\hline 10 & Komazaki et al 2018 & 1 & 1 & 0 & 1 & 0 & 1 & 0 & 4 \\
\hline 11 & Nakahara et al 2018 & 1 & 1 & 0 & 1 & 0 & 1 & 1 & 5 \\
\hline
\end{tabular}


Figure 1: Flow chart of the study search strategy
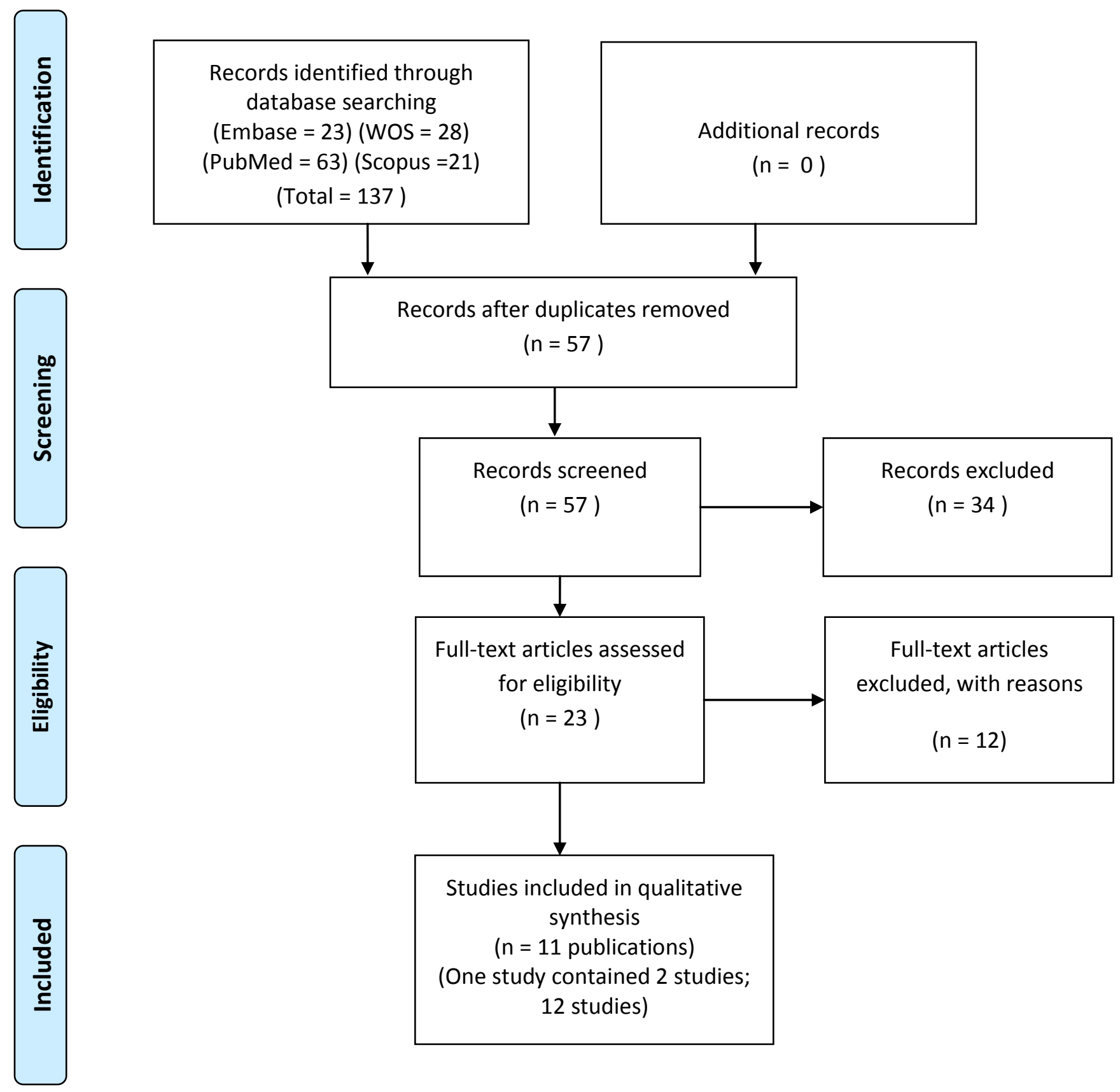
AHMAD, A., FURUTA, M., SHINAGAWA, T., TAKEUCHI, K., TAKESHITA, T., SHIMAZAKI, Y. \& YAMASHITA, Y. 2015. Association of periodontal status with liver abnormalities and metabolic syndrome. $J$ Oral Sci, 57, 335-43.

AKINKUGBE, A. A., AVERY, C. L., BARRITT, A. S., COLE, S. R., LERCH, M., MAYERLE, J., OFFENBACHER, S., PETERSMANN, A., NAUCK, M., VOLZKE, H., SLADE, G. D., HEISS, G., KOCHER, T. \& HOLTFRETER, B. 2017a. Do Genetic Markers of Inflammation Modify the Relationship between Periodontitis and Nonalcoholic Fatty Liver Disease? Findings from the SHIP Study. J Dent Res, 96, 1392-1399.

AKINKUGBE, A. A., BARRITT, A. S., CAI, J., OFFENBACHER, S., THYAGARAJAN, B., KHAMBATY, T., SINGER, R., KALLWITZ, E., HEISS, G. \& SLADE, G. D. 2018. Periodontitis and prevalence of elevated aminotransferases in the hispanic community health study/study of latinos. J Periodontol.

AKINKUGBE, A. A., SLADE, G. D., BARRITT, A. S., COLE, S. R., OFFENBACHER, S., PETERSMANN, A., KOCHER, T., LERCH, M. M., MAYERLE, J., VOLZKE, H., HEISS, G. \& HOLTFRETER, B. 2017b. Periodontitis and Non-alcoholic Fatty Liver Disease, a population-based cohort investigation in the Study of Health in Pomerania. J Clin Periodontol, 44, 1077-1087.

ALAZAWI, W., BERNABE, E., TAI, D., JANICKI, T., KEMOS, P., SAMSUDDIN, S., SYN, W. K., GILLAM, D. \& TURNER, W. 2017. Periodontitis is associated with significant hepatic fibrosis in patients with non-alcoholic fatty liver disease. PLoS One, 12, e0185902.

ANSTEE, Q. M., TARGHER, G. \& DAY, C. P. 2013. Progression of NAFLD to diabetes mellitus, cardiovascular disease or cirrhosis. Nat Rev Gastroenterol Hepatol, 10, 330-44.

ARAUJO, A. R., ROSSO, N., BEDOGNI, G., TIRIBELLI, C. \& BELLENTANI, S. 2018. Global epidemiology of non-alcoholic fatty liver disease/non-alcoholic steatohepatitis: What we need in the future. Liver Int, 38 Suppl 1, 47-51.

BEUKERS, N. G., VAN DER HEIJDEN, G. J., VAN WIJK, A. J. \& LOOS, B. G. 2017. Periodontitis is an independent risk indicator for atherosclerotic cardiovascular diseases among 60174 participants in a large dental school in the Netherlands. J Epidemiol Community Health, 71, 37-42.

CHUNG, J. H., HWANG, H. J., KIM, S. H. \& KIM, T. H. 2016. Associations Between Periodontitis and Chronic Obstructive Pulmonary Disease: The 2010 to 2012 Korean National Health and Nutrition Examination Survey. J Periodontol, 87, 864-71.

CORBELLA, S., VERONESI, P., GALIMBERTI, V., WEINSTEIN, R., DEL FABBRO, M. \& FRANCETTI, L. 2018. Is periodontitis a risk indicator for cancer? A meta-analysis. PLoS One, 13, e0195683.

DESCHAMPS-LENHARDT, S., MARTIN-CABEZAS, R., HANNEDOUCHE, T. \& HUCK, O. 2018. Association between periodontitis and chronic kidney disease: Systematic review and meta-analysis. Oral Dis.

FURUSHO, H., MIYAUCHI, M., HYOGO, H., INUBUSHI, T., AO, M., OUHARA, K., HISATUNE, J., KURIHARA, H., SUGAI, M., HAYES, C. N., NAKAHARA, T., AIKATA, H., TAKAHASHI, S., CHAYAMA, K. \& TAKATA, T. 2013. Dental infection of Porphyromonas gingivalis exacerbates high fat diet-induced steatohepatitis in mice. J Gastroenterol, 48, 1259-70.

FURUTA, M., EKUNI, D., YAMAMOTO, T., IRIE, K., KOYAMA, R., SANBE, T., YAMANAKA, R., MORITA, M., KUROKI, K. \& TOBE, K. 2010. Relationship between periodontitis and hepatic abnormalities in young adults. Acta Odontol Scand, 68, 27-33.

GBD 2015 DISEASE AND INJURY INCIDENCE AND PREVALENCE COLLABORATORS 2016. Global, regional, and national incidence, prevalence, and years lived with disability for 310 diseases and injuries, 1990-2015: a systematic analysis for the Global Burden of Disease Study 2015. Lancet, 388, 1545-1602. 
GIL-MONTOYA, J. A., SANCHEZ-LARA, I., CARNERO-PARDO, C., FORNIELES, F., MONTES, J., VILCHEZ, R., BURGOS, J. S., GONZALEZ-MOLES, M. A., BARRIOS, R. \& BRAVO, M. 2015. Is periodontitis a risk factor for cognitive impairment and dementia? A case-control study. J Periodontol, 86, 244-53.

GOMES-FILHO, I. S., DE OLIVEIRA, T. F., DA CRUZ, S. S., PASSOS-SOARES JDE, S., TRINDADE, S. C., OLIVEIRA, M. T., SOUZA-MACHADO, A., CRUZ, A. A., BARRETO, M. L. \& SEYMOUR, G. J. 2014. Influence of periodontitis in the development of nosocomial pneumonia: a case control study. $J$ Periodontol, 85, e82-90.

GULATI, M., ANAND, V., JAIN, N., ANAND, B., BAHUGUNA, R., GOVILA, V. \& RASTOGI, P. 2013. Essentials of periodontal medicine in preventive medicine. Int J Prev Med, 4, 988-94.

HASUIKE, A., IGUCHI, S., SUZUKI, D., KAWANO, E. \& SATO, S. 2017. Systematic review and assessment of systematic reviews examining the effect of periodontal treatment on glycemic control in patients with diabetes. Med Oral Patol Oral Cir Bucal, 22, e167-e176.

HYVARINEN, K., TUOMAINEN, A. M., LAITINEN, S., BYKOV, I. L., TORMAKANGAS, L., LINDROS, K., KAKELA, R., ALFTHAN, G., SALMINEN, I., JAUHIAINEN, M., KOVANEN, P. T., LEINONEN, M., SAIKKU, P. \& PUSSINEN, P. J. 2009. Chlamydial and periodontal pathogens induce hepatic inflammation and fatty acid imbalance in apolipoprotein E-deficient mice. Infect Immun, 77, 3442-9.

KASSEBAUM, N. J., BERNABE, E., DAHIYA, M., BHANDARI, B., MURRAY, C. J. \& MARCENES, W. 2014a. Global burden of severe periodontitis in 1990-2010: a systematic review and meta-regression. $J$ Dent Res, 93, 1045-53.

KASSEBAUM, N. J., BERNABE, E., DAHIYA, M., BHANDARI, B., MURRAY, C. J. \& MARCENES, W. $2014 \mathrm{~b}$. Global Burden of Severe Tooth Loss: A Systematic Review and Meta-analysis. J Dent Res, 93, 20S-28S.

KOMAZAKI, R., KATAGIRI, S., TAKAHASHI, H., MAEKAWA, S., SHIBA, T., TAKEUCHI, Y., KITAJIMA, Y., OHTSU, A., UDAGAWA, S., SASAKI, N., WATANABE, K., SATO, N., MIYASAKA, N., EGUCHI, Y., ANZAI, K. \& IZUMI, Y. 2017. Periodontal pathogenic bacteria, Aggregatibacter actinomycetemcomitans affect non-alcoholic fatty liver disease by altering gut microbiota and glucose metabolism. Sci Rep, 7, 13950.

KUMAR, N., BHARDWAJ, A., NEGI, P. C., JHINGTA, P. K., SHARMA, D. \& BHARDWAJ, V. K. 2016. Association of chronic periodontitis with metabolic syndrome: A cross-sectional study. J Indian Soc Periodontol, 20, 324-9.

KUMAR, P. S. 2017. From focal sepsis to periodontal medicine: a century of exploring the role of the oral microbiome in systemic disease. J Physiol, 595, 465-476.

KURAJI, R., ITO, H., FUJITA, M., ISHIGURO, H., HASHIMOTO, S. \& NUMABE, Y. 2016. Porphyromonas gingivalis induced periodontitis exacerbates progression of non-alcoholic steatohepatitis in rats. Clin Exp Dent Res, 2, 216-225.

LI, Q., HAO, S., FANG, J., XIE, J., KONG, X. H. \& YANG, J. X. 2015. Effect of non-surgical periodontal treatment on glycemic control of patients with diabetes: a meta-analysis of randomized controlled trials. Trials, 16, 291.

LINDEN, G. J., HERZBERG, M. C. \& WORKING GROUP 4 OF THE JOINT, E. F. P. A. A. P. W. 2013. Periodontitis and systemic diseases: a record of discussions of working group 4 of the Joint EFP/AAP Workshop on Periodontitis and Systemic Diseases. J Periodontol, 84, S20-3.

LINS, L., BITTENCOURT, P. L., EVANGELISTA, M. A., LINS, R., CODES, L., CAVALCANTI, A. R., PARANA, R. \& BASTOS, J. 2011. Oral health profile of cirrhotic patients awaiting liver transplantation in the Brazilian Northeast. Transplant Proc, 43, 1319-21.

LISTL, S., GALLOWAY, J., MOSSEY, P. A. \& MARCENES, W. 2015. Global Economic Impact of Dental Diseases. J Dent Res, 94, 1355-61. 
LOOS, B. G., CRAANDIJK, J., HOEK, F. J., WERTHEIM-VAN DILLEN, P. M. \& VAN DER VELDEN, U. 2000. Elevation of systemic markers related to cardiovascular diseases in the peripheral blood of periodontitis patients. J Periodontol, 71, 1528-34.

MEYLE, J. \& CHAPPLE, I. 2015. Molecular aspects of the pathogenesis of periodontitis. Periodontol 2000, 69, 7-17.

MOHER, D., SHAMSEER, L., CLARKE, M., GHERSI, D., LIBERATI, A., PETTICREW, M., SHEKELLE, P. \& STEWART, L. A. 2015. Preferred reporting items for systematic review and meta-analysis protocols (PRISMA-P) 2015 statement. Systematic reviews, 4, 1.

MORITA, T., YAMAZAKI, Y., FUJIHARU, C., ISHII, T., SETO, M., NISHINOUE, N., SASAKI, Y., KAWATO, T., MOTOHASHI, M. \& MAENO, M. 2014. Serum $\gamma$-glutamyltransferase level is associated with periodontal disease independent of drinking habits in Japanese adults. Medical science monitor: international medical journal of experimental and clinical research, 20, 2109.

NAGAO, Y., KAWAHIGASHI, Y. \& SATA, M. 2014. Association of Periodontal Diseases and Liver Fibrosis in Patients With HCV and/or HBV infection. Hepat Mon, 14, e23264.

NAKAHARA, T., HYOGO, H., ONO, A., NAGAOKI, Y., KAWAOKA, T., MIKI, D., TSUGE, M., HIRAGA, N., HAYES, C. N., HIRAMATSU, A., IMAMURA, M., KAWAKAMI, Y., AIKATA, H., OCHI, H., ABECHAYAMA, H., FURUSHO, H., SHINTANI, T., KURIHARA, H., MIYAUCHI, M., TAKATA, T., ARIHIRO, K. \& CHAYAMA, K. 2018. Involvement of Porphyromonas gingivalis in the progression of nonalcoholic fatty liver disease. J Gastroenterol, 53, 269-280.

NEUSCHWANDER-TETRI, B. A. \& CALDWELL, S. H. 2003. Nonalcoholic steatohepatitis: summary of an AASLD Single Topic Conference. Hepatology, 37, 1202-19.

OMURA, Y., KITAMOTO, M., HYOGO, H., YAMANOUE, T., TADA, Y., BOKU, N., NISHISAKA, T., MIYAUCHI, M., TAKATA, T. \& CHAYAMA, K. 2016. Morbidly obese patient with non-alcoholic steatohepatitisrelated cirrhosis who died from sepsis caused by dental infection of Porphyromonas gingivalis: $A$ case report. Hepatol Res, 46, E210-5.

PONZIANI, F. R., BHOORI, S., CASTELLI, C., PUTIGNANI, L., RIVOLTINI, L., DEL CHIERICO, F., SANGUINETTI, M., MORELLI, D., PARONI STERBINI, F., PETITO, V., REDDEL, S., CALVANI, R., CAMISASCHI, C., PICCA, A., TUCCITTO, A., GASBARRINI, A., POMPILI, M. \& MAZZAFERRO, V. 2018. Hepatocellular Carcinoma is Associated with Gut Microbiota Profile and Inflammation in Non-Alcoholic Fatty Liver Disease. Hepatology.

POTEMPA, J., MYDEL, P. \& KOZIEL, J. 2017. The case for periodontitis in the pathogenesis of rheumatoid arthritis. Nat Rev Rheumatol, 13, 606-620.

SAITO, T., SHIMAZAKI, Y., KOGA, T., TSUZUKI, M. \& OHSHIMA, A. 2006. Relationship between periodontitis and hepatic condition in Japanese women. J Int Acad Periodontol, 8, 89-95.

TAKAMURA, H., YOSHIDA, K., OKAMURA, H., FUJIWARA, N. \& OZAKI, K. 2016. Porphyromonas gingivalis attenuates the insulin-induced phosphorylation and translocation of forkhead box protein $\mathrm{O} 1 \mathrm{in}$ human hepatocytes. Arch Oral Biol, 69, 19-24.

TOMOFUJI, T., EKUNI, D., SANBE, T., AZUMA, T., TAMAKI, N., IRIE, K., MARUYAMA, T., YAMAMOTO, T., WATANABE, T., MIYAUCHI, M. \& TAKATA, T. 2009. Effects of improvement in periodontal inflammation by toothbrushing on serum lipopolysaccharide concentration and liver injury in rats. Acta Odontol Scand, 67, 200-5.

VANDENBROUCKE, J. P., VON ELM, E., ALTMAN, D. G., GOTZSCHE, P. C., MULROW, C. D., POCOCK, S. J., POOLE, C., SCHLESSELMAN, J. J., EGGER, M. \& INITIATIVE, S. 2014. Strengthening the Reporting of Observational Studies in Epidemiology (STROBE): explanation and elaboration. Int J Surg, 12, 1500-24.

VASCONCELOS, D. F., PEREIRA DA SILVA, F. R., PINTO, M. E., SANTANA, L. A., SOUZA, I. G., MIRANDA DE SOUZA, L. K., OLIVEIRA, N. C., VENTURA, C. A., NOVAES, P. D., BARBOSA, A. L., MEDEIROS, J. R., 
MIKOLASEVIC, I., MANI, A. \& SOARES DE OLIVEIRA, J. 2017. Decrease of Pericytes is Associated With Liver Disease Caused by Ligature-Induced Periodontitis in Rats. J Periodontol, 88, e49-e57.

WIDITA, E., YOSHIHARA, A., HANINDRIYO, L. \& MIYAZAKI, H. 2018. Relationship between clinical periodontal parameters and changes in liver enzymes levels over an 8-year period in an elderly Japanese population. J Clin Periodontol, 45, 311-321.

YONEDA, M., NAKA, S., NAKANO, K., WADA, K., ENDO, H., MAWATARI, H., IMAJO, K., NOMURA, R., HOKAMURA, K., ONO, M., MURATA, S., TOHNAI, I., SUMIDA, Y., SHIMA, T., KUBONIWA, M., UMEMURA, K., KAMISAKI, Y., AMANO, A., OKANOUE, T., OOSHIMA, T. \& NAKAJIMA, A. 2012. Involvement of a periodontal pathogen, Porphyromonas gingivalis on the pathogenesis of nonalcoholic fatty liver disease. BMC Gastroenterol, 12, 16. 